\title{
Day-time concentrations of biogenic volatile organic compounds in a boreal forest canopy and their relation to environmental and biological factors
}

\author{
H. K. Lappalainen ${ }^{1,2}$, S. Sevanto ${ }^{2}$, J. Bäck ${ }^{3}$, T. M. Ruuskanen ${ }^{2}$, P. Kolari ${ }^{3}$, R. Taipale ${ }^{2}$, J. Rinne ${ }^{2}$, M. Kulmala ${ }^{2}$, and \\ P. Hari $^{3}$ \\ ${ }^{1}$ Finnish Meteorological Institute, P. O. Box 503, 00101 Helsinki, Finland \\ ${ }^{2}$ Department of Physics, P. O. Box 64, 00014 University of Helsinki, Finland \\ ${ }^{3}$ Department of Forest Ecology, P. O. Box 27, 00014 University of Helsinki, Finland
}

Received: 29 January 2009 - Published in Atmos. Chem. Phys. Discuss.: 9 March 2009

Revised: 11 June 2009 - Accepted: 29 June 2009 - Published: 3 August 2009

\begin{abstract}
Atmospheric concentrations of methanol, acetaldehyde, acetone, isoprene and monoterpenes were measured using PTR-MS (proton transfer reaction mass spectrometry) in a boreal forest site in Hyytiälä, Finland $\left(61^{\circ} 51^{\prime} \mathrm{N}, 24^{\circ} 17^{\prime} \mathrm{E}\right)$. The concentration measurements were made in the upper canopy of a Scots pine forest during 6 June, 2006-31 August, 2007. Meteorological variables such as temperature and photosynthetically active radiation were measured simultaneously. We also detected biologically sensitive turnover points such as the onsets of photosynthetic activity, onset of growing season, bud burst and stem growth during the annual cycle and compared them to changes in BVOC (biogenic volatile organic compound) concentrations. A typical seasonal pattern of winter minimum and summer maximum was found for all studied compounds except acetaldehyde. Spring time methanol and acetone concentrations increased together with photosynthetic capacity. The day-time daily median BVOC concentrations correlated best with air temperature. The intercorrelations between compounds and the analysis of meteorological conditions indicated that the measured concentrations presented well the local source. During an exceptional summer drought period the concentrations were neither connected with photosynthesis nor transpiration, but they were regulated by some other, yet unknown factors.
\end{abstract}

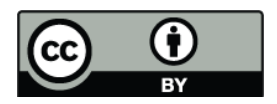

Correspondence to: H. K. Lappalainen (hanna.k.lappalainen@helsinki.fi)

\section{Introduction}

Forests are a significant source of volatile organic compound (VOC) emissions. Globally, the emissions from boreal areas are less than those from temperate or tropical regions, but their contribution to regional BVOC (biogenic volatile organic compound) budget is significant (Guenther et al., 1995). Studies of BVOC emissions from the boreal forest zone consider mostly monoterpenes and isoprene, but boreal forests also emit methanol, acetone and acetaldehyde (Janson et al., 1999; Janson and Serves, 2001; Rinne et al., 2007). The emitted compounds differ between the major boreal tree species. Scots pine (Pinus sylvestris L.) and Norway spruce (Picea abies L. Karst.) and some deciduous tree species like silver birch (Betula pubescens Ehrh.) are mainly monoterpene emitters, whereas trembling aspen (Populus tremula L.) and willow (Salix) species emit mostly isoprene (Janson and Serves, 2001; Hakola et al., 2000). Once emitted into the atmosphere, the BVOCs may participate in the secondary organic aerosol (SOA) growth which is part of the atmospheric particle formation processes critical to the climate system (Kourtchev et al., 2008; Kulmala et al., 2004, 2007; Tunved et al., 2006).

The BVOC concentrations in the atmospheric boundary layer are affected by several biological and physical processes of different temporal and spatial scales. First, there are the emissions from the biological sources (here plants) that depend on physiological status of plants and their reactions to the environment (PPFD, temperature, stress etc.) as well as plant internal capacity to produce BVOCs (seasonal

Published by Copernicus Publications on behalf of the European Geosciences Union. 
effect) and the size of plant BVOC storage and their possible reactions to the environment. Second, the atmospheric concentrations are affected by the chemical reactivity of a substance, the long range transport and the mixing of the atmosphere.

The central plant physiological processes in question here are photosynthesis, growth and specific, defence-related metabolism which starts to take place under stress. Isoprene and monoterpenes are synthesized in processes related to the biosynthesis of carotenoids in the chloroplasts. Their formation is thus regulated at least partly by the same factors (Owen and Penuelas, 2005). The substrates involved in their biosynthesis are derived from the Calvin cycle, and therefore a direct link to photosynthesis has been postulated and formulated in a physiological model framework describing emissions of isoprene (Niinemets et al., 1999) and monoterpenes (Bäck et al., 2005). Methanol emissions, on the other hand, seem to be related to growth. Methanol is produced during cell wall expansion in pectin biosynthesis process (Galbally and Kirstine, 2002). Acetaldehyde and acetone can be derived from several metabolic routes (Fall, 2003). Acetaldehyde, for example, can be produced during lightdark transitions as a result of sun flecks that increase cytosolic pyruvic acid or as a result of metabolism in anaerobic roots (oxygen deficiency in the soil - soil flooding) or during senescence and leaf wounding (Kreuzwieser et al., 2004). Acetone is produced in both light-dependent and independent processes, which may be related to the decarboxylation of acetoacetate (Fall, 2003).

Previous studies have shown that the most important environmental factors controlling the isoprene, monoterpene and methanol emissions are air temperature (Tingey et al., 1980) together with light intensity (Guenther et al., 1991; Folkers et al., 2008). Plants are constantly changing the physiological status and acclimate to the environment following cues from their environment during previous hours, days or even seasons (Öquist and Huner, 2003; Mäkelä et al., 2004). It is very probable that environmental factors together with plant physiological status influence also the BVOC metabolism in a comparable time scale (Guenther 1997; Monson et al., 1995; Grote and Niinemets, 2008).

Recent progress in on-line field measurement techniques, such as proton transfer reaction mass spectrometry (PTRMS) enables long-term measurements of VOC compounds (Lindinger et al., 1998) and holistic studies of the effects of changing climate and biological controls on VOC concentrations (Fall, 2003). Long term in-situ measurements are especially important in the areas like boreal forests which are characterized by potentially high BVOC emission. In many cases BVOC emission measurements are made on a leaf and/or branch scale (shoot chamber technique) and then scaled up to present canopy emissions or atmospheric concentrations using canopy scale models (Grote and Niinemets, 2008). Contrary to that approach, air concentration measurements provide data measured directly at forest canopy scale.
However, it remains for each study to show whether they represent the canopy emissions at the particular situation.

The capacity for BVOC biosynthesis in perennial plants may vary during the annual cycle. Sensitive periods such as the onset of photosynthesis, internal allocation of photoassimilated carbon and different phenological phases like bud burst along with increasing leaf area and mass in spring could stimulate daily BVOC emissions. In this study we present the seasonal courses of five BVOC compounds at the upper canopy level of a boreal Scots pine forest. First we evaluate how well the concentrations represent local emissions and then we trace the linkage between the concentrations and biological activity in canopy scale. Finally, we determine which environmental factors predict the measured concentrations best. We analyse the linkage between concentrations and biologic activity in seasonal and daily scale. Our aim was to determine how well air concentration measurements of BVOCs can be linked with the potential emission activity of the forest.

\section{Material and methods}

\subsection{Measurement site}

All the measurements were carried out at the SMEAR-II station (Station for Measuring Forest Ecosystem - Atmosphere Relations), which is located in the boreal forest in Hyytiälä $\left(61^{\circ} 51^{\prime} \mathrm{N}, 24^{\circ} 17^{\prime} \mathrm{E}, 181 \mathrm{~m}\right.$ a.s.l.), southern Finland (Hari and Kulmala, 2005). The typical landscape surrounding the station $5 \mathrm{~km}$ to every direction includes evenly distributed stands of pine, spruce and mixed forests (Fig. 1). The forest at the station is a homogeneous 47-year-old (16 $\mathrm{m}$ in height) Scots pine (Pinus sylvestris L.) stand originally planted from seed in 1962. The Scots pine and spruce (Picea abies L. Karst.) represented 79\% of trees with DBH (Tree diameter at breast height) $>5 \mathrm{~cm}$ in the stand. However broadleaved tree species (Norway spruce (Picea abies L. Karst.), trembling aspen (Populus tremula L.), white birch (Betula pubescens Ehrh.), grey alder (Alnus incana L. Moench)) represented $63 \%$ of trees per ha (Ilvesniemi et al. , 2009). Typical species covering the ground layer are heather (Calluna vulgaris L.), lingonberry (Vaccinium vitis-idaea) and blueberry (V. myrtillus). The forest soil type is haptic podzol.

The station is located in a sparsely populated area of a municipality Juupajoki. The only source of VOCs external to the forests are two sawmills and a pellet factory in Korkeakoski village, approximately $15 \mathrm{~km}$ South-East from the station. The annual processed log volume in the local wood industry is ca. $950000 \mathrm{~m}^{3}$. During summer the industry is closed for about one month in July. The industrial VOC emissions originate from drying and processing softwood, mainly pine and spruce. 


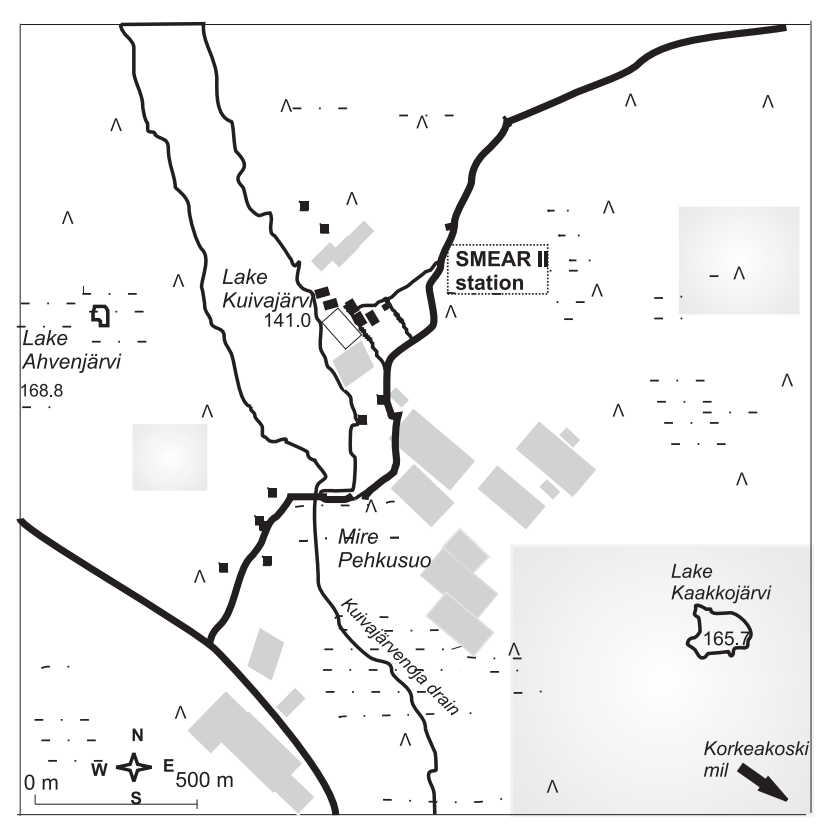

Fig. 1. A $4 \mathrm{~km}^{2}$ map of the SMEAR II station; forest harvesting areas are marked with light gray squares, agricultural fields with dark gray rectangulars, buildings with black squares, wetlands and mires with cross-line and forest with $\wedge$.

\subsection{BVOC measurements}

The BVOC concentrations (volume mixing ratios) [ppbv] were measured at the upper canopy level (14 m height) using the PTR-MS system described in more detail by Taipale et al. (2008) and Ruuskanen et al. (2009). Every second or third hour the ambient BVOC concentration was measured by taking 15-25 samples per hour. In this paper, we present concentrations of methanol (detected at $33 \mathrm{amu}, \mathrm{M33}$ ), acetaldehyde (M45), acetone (M59), isoprene and methylbutenol (MBO) (M69), and monoterpenes (M137). The PTR-MS measures concentrations according to molecular masses. The masses presented here may also contain other compounds of similar mass. From here on, however, we call the mass classes by the name of the BVOC compounds that form the major part of the material detected by that mass class. The PTR-MS was calibrated regularly with a gas standard (Taipale et al., 2008; Ruuskanen et al., 2009). The detection limits for individual measurements with an integration time of $2 \mathrm{~s}$ were: M33 300 pptv, M45 76 pptv, M59 74 pptv, M69 53 pptv and M137 46 pptv (Taipale et al., 2008).

The data were collected during fifteen months, between 6 June, 2006-31 August, 2007. To be able to correlate concentrations with plant physiological activity, we divided the dataset into seasons based on calendar months (Table 1). To make the dataset representative of the postulated maximum emissions, we used day-time medians of the BVOC concentrations (Table 1). The time windows specified for each
Table 1. The time windows (local time, GMT+2) used for calculating the day-time median concentrations at the seasonal and monthly scale.

\begin{tabular}{llr}
\hline Season & Months & Time window \\
\hline Summer 2006, 2007 & June & 07:00 a.m.-18:00 p.m. \\
Summer 2006, 2007 & July & 07:00 a.m.-18:00 p.m. \\
Summer 2006, 2007 & August & 07:00 a.m.-18:00 p.m. \\
Autumn 2006 & September & 09:00 a.m.-16:00 p.m. \\
Winter 2006 & December & 11:00 a.m.-16:00 p.m. \\
Winter 2007 & January & 11:00 a.m.-16:00 p.m. \\
Winter 2007 & February & 11:00 a.m.-16:00 p.m. \\
Spring 2007 & March & 09:00 a.m.-17:00 p.m. \\
Spring 2007 & April & 09:00 a.m.-17:00 p.m. \\
Spring 2007 & May & 09:00 a.m.-17:00 p.m. \\
\hline
\end{tabular}

season represented the time when the sun is high enough to cause atmospheric mixing (Rinne et al., 2005). Furthermore the daytime observations presented the gas exchange from stomata to air rather than the VOC deposition to leaves, which may occur during night. The number of observations varied between seasons due to temporary failures of the measurement system. The longest gap in the dataset was from 26 September to 29 November, 2006.

\subsection{Meteorological and biological measurements}

Meteorological data were obtained from standard half-hourly micrometeorological measurements at the SMEAR-II station. Air temperature was measured at $8.4 \mathrm{~m}$ using a ventilated and shielded Pt-100 sensor. Precipitation was sampled with bottles or buckets. Soil temperature (humus layer at $5 \mathrm{~cm}$ ) and photosynthetically active photon flux density (PPFD, 400-700 nm) were detected by a thermistor and a quantum sensor (Li-Cor LI-190SZ), respectively. Wind speed and direction were obtained from ultrasonic anemometers (Thies Ultrasonic Anemometer 2-D). For a more detailed description of the measurement systems see Vesala et al. (1998).

We also measured net ecosystem exchange (NEE) using the eddy covariance method (sonic anemometer with gas analyzer Solent 1012R2). Wind speed and $\mathrm{CO}_{2}$ concentration were measured with frequency of $10 \mathrm{~Hz}$ and the $\mathrm{CO}_{2-}$ flux was calculated from the covariance of the vertical wind speed and $\mathrm{CO}_{2}$ concentration fluctuation and averaged over $30 \mathrm{~min}$. Total ecosystem respiration (TER) was estimated from the nighttime NEE and extrapolated to cover daytime using a temperature regression on organic layer temperature (see Mäkelä et al., 2006). Gross primary production (GPP) was calculated by subtracting TER from NEE. When measured NEE was rejected or missing, GPP was directly estimated as a saturating function of PPFD. Note that GPP is positive when $\mathrm{CO}_{2}$ flux is towards the canopy and NEE is negative. 
Soil water content, used for the determination of the drought period, was measured continuously at several locations and depths using the time domain reflectometry (TDR) method (TDR100, Campbell Scientific, Logan, UT, USA). The drought period was defined as a period when volumetric soil water content in the mineral soil was below $0.15 \mathrm{~m}^{3} / \mathrm{m}^{3}$ (B horizon $30 \mathrm{~cm}$ ). This value corresponds to soil water potential of $-2 \mathrm{MPa}$ and B-horizon represents the depth where the trees take most of the water (Duursma et al., 2008). In the summer of 2006 the soil water content was below the limit value from 20 June to 30 August (data not shown). The effect of drought on the gas exchange of trees was detected in the end of July and a significant decrease was observed in July-August. Summer 2006 was the driest summer detected at SMEAR II station during the whole 12 years of measurements.

The secondary growth of the Scots pine stems was measured using linear displacement transducers (LVDT; A/5.0/S Solartron Inc., West Sussex, UK) on four representatives of the dominant pine trees. The LVDTs were attached on rectangular steel frames mounted around the stems at about $2 \mathrm{~m}$ height. The stem diameter was recorded with the frequency of $1 / \mathrm{min}$ and the diurnal diameter variation resulting from changing water tension inside the xylem was eliminated by using daily mean diameters. Xylem water tension is controlled by the difference between soil water uptake and transpiration. Transpiration can be seen as a consequence of stomatal opening for carbon intake to be used in photosynthesis. When the stomata are open, the stem shrinks and when they are closed the stem swells. This applies as well to the diurnal cycle as to long-term changes. Rainfall can be seen as an overall increase in stem diameter and drought as an overall shrinkage. Therefore, in addition to being an indicator of secondary growth, changes in stem diameter can be used for detecting the water status of the plant (Sevanto et al., 2005). The changes in the diameter of the Scots pine stems were measured during 1 May-31 October, 2006.

The daily shoot and needle growth of Scots pine was measured on four trees, at four heights in the mornings (09:00 a.m.) at least twice a week. The marked main and lateral shoots were measured from 21 May to 11 June and needles from 12 June to 8 August, 2007.

\subsection{Indicators for biological activity}

\subsubsection{State of development, $S$}

In boreal evergreen species, seasonal changes in photosynthetic activity are pronounced, and a number of processes are influenced by these variations (Öquist and Huner, 2003). As an indicator of changes in photosynthetic capacity of the trees we used the state of development, parameter $S$, formulated by Mäkelä et al. (2004). $S$ follows ambient temperature $\left(T,{ }^{\circ} \mathrm{C}\right)$ in a delayed manner as $\frac{d S}{d t}=\frac{T-S}{\tau}$

where $\tau$ is a time constant (here $200 \mathrm{~h}$, see Kolari et al., 2007). Photosynthetic capacity in Scots pine is related to $S$ via, approximately, sigmoidal relationship.

\subsubsection{Thermal Time (TT)}

A Thermal Time (TT) (Sarvas,1972) model was used to determine the start of bud burst of deciduous trees in spring at SMEAR-II station. TT model is the most straightforward type of phenological models describing the start of bud development from a fixed calendar date in spring. The TT model assumes that the environmental conditions required to release the dormancy have taken place before the fixed starting date of temperature sum accumulation onset. The starting date for the temperature sum accumulation can be considered to represent environmental features that take place at the same time in each year, the likely candidate being a changing day length (Linkosalo and Lechowicz, 2006; Linkosalo et al., 2008). $D(t)$ is a temperature sum considered to represent a stage of phenological event and is the sum of the positive differences (the rate of temperature accumulation $r(T)$ ), between diurnal mean temperatures over critical temperature threshold $\left(T_{\text {crit }}\right)$ value.

$$
\begin{aligned}
& r(T)=\left\{\begin{array}{rll}
T-T_{\text {crit }}: & T>T_{\text {crit }}, \\
0 & : & T<T_{\text {crit }}
\end{array}\right. \\
& D(t)=\sum_{t=t_{0}}^{t} r(T) \Delta t
\end{aligned}
$$

The forests near SMEAR II are mainly coniferous, but unfortunately the parameter values (onset date for the temperature sum accumulation, critical temperature sum threshold) have not been determined for Scots pine or Norway spruce. Therefore, we used the published values for birch and supposed that they can be used as a proxy for the general dormancy release status of tree foliage at the stand. The parameter values for birch (Betula pubescens) leaf bud burst were obtained from Linkosalo et al. (2008). The starting date for temperature sum accumulation was 26 February, the critical temperature sum threshold $1.5^{\circ} \mathrm{C}$ and the critical temperature sum threshold 134 day degrees.

\section{Results and discussion}

\subsection{Analysis of BVOC transport}

Although the forest surrounding the SMEAR II site is rather homogenous, the local BVOC concentration could be affected by emissions transported from nearby sources, especially when compounds with long atmospheric lifetime are concerned (Rinne et al., 2007). The effect of BVOC transport from sources other than the local forest (mainly the saw 
mills in the South-East direction) on the measured concentrations was analyzed using wind roses. Most clear evidence of transported BVOC concentrations was found for monoterpenes and isoprene (Fig. 2). Despite the long lifetime of methanol and acetone, the high concentrations seemed to come quite evenly from all directions. This could also be a result of atmospheric secondary production (Legreida et al., 2007), which peaks at the same time with photosynthesis (high temperature and radiation). However, our measurements were made at the top canopy level where atmospheric mixing is high during daytime and therefore the concentrations can be said to represent the local emission from the forest. The main sources for transported BVOCs are in the East (Korkeakoski Village) and South-East (the saw mills). The dominant wind direction at SMEAR II station in all seasons is West and South-West. However, to be sure that the main potential source of transported BVOCs would not affect our analysis, we filtered out the concentrations measured during the South-East wind in further analysis. In our case sawmill processes could have been an extra source especially for monoterpene concentrations. Also the local forest logging activities could have affected the air concentrations (emissions from stumps and cut wood). According to information from local forestry authorities, several forest fells and other harvesting operations (size of $0.5 \mathrm{ha} . . .10 \mathrm{ha}$ ) were carried out in the $0.7-3.5 \mathrm{~km}$ distance of the measurement site 2-3 months before or during the measurement period (see Fig. 1). We did not filter these directions because loggings and forest management are a common practise in Finland and we could not identify high concentration peaks to particular operations.

\subsection{BVOC concentrations}

All the compounds except acetaldehyde showed clear seasonal differences in the monthly day-time median concentrations (Fig. 3). The concentrations were in minimum during the winter and in maximum during the summer. Acetaldehyde concentrations were almost independent of the season. We analysed changing concentration levels together with the photosynthetic capacity (state of development, $S$ ) and compared the occurrence of daily peak BVOC concentrations to simultaneous biologically sensitive (point) events such as growth rate of stems, shoots and needles, leaf development (bud burst) and photosynthesis for each compound separately.

Methanol. In the autumn, the median monthly daytime methanol concentrations were around $1 \mathrm{ppbv}$, in spring $0.5 \mathrm{ppbv}$ and in summer around $2 \mathrm{ppbv}$ (Fig. 3). These concentrations were clearly lower than those reported for a mixed hardwood forest in the US $(4,8,10 \mathrm{ppbv}$, respectively; Karl et al., 2003) or in the Duke forest in a loblolly pine plantation (5.8 ppbv) (Karl et al., 2005). The lower seasonal concentration levels at our site are most likely related to the species composition and other site-specific fac- tors. Hyytiälä observation site is dominated by Scots pine, while the mixed hardwood forest was dominated by aspen species, and the Duke stand also had some sweet gum as understorey growth. Signficant differences may exist among plant species in their methanol emission capacity, due to e.g. differences in the fraction of cell walls and pectin content of leaves (Galbally and Kirstine, 2002). Also, in a temperate ecosystem the emissions from decaying plant material (Warneke et al.,1999) may be larger than in a relatively cool boreal coniferous stand.

The increasing photosynthetic capacity in the spring (2007), described by the "state of development" parameter $S$ (Eq. 1), correlated well ( $r=0.72)$ with methanol concentrations between 15 March and 31 May. After that, $S$ could not predict the measured concentrations (Fig. 4). Methanol is formed during cell wall expansion in pectin biosynthesis process (Galbally and Kirstine, 2002) and therefore it is likely that the increasing concentrations during spring could be related to increasing leaf area in spring and photosynthetic activity.

In summer 2006 there were three periods of clearly elevated methanol concentration peaks (Fig. 5). The first maximum concentration, $7.0 \mathrm{ppbv}$, was observed on 13 June. According to long-term recordings of Hyytiälä area, the bud burst of birch (Betula pendula/pubescens L.) takes place in mid-May (Lappalainen and Heikinheimo, 1992) and the full leaf area of deciduous tree species is reached in the second week of June. The observed maximum day-time concentration of $7 \mathrm{ppbv}$ is, however, a decade lower than what has been earlier measured in springtime in a mixed hardwood forest or in a pine plantation (Karl et al.,2003; Schade and Goldstein, 2006).

The second peak concentration occurred in the beginning of July. At that time the total ecosystem respiration (TER) started to increase (Fig. 6) and the growth rate of the stems decreased showing even stem shrinkage (Fig. 5), which resulted from drying soil. The third peak occurred later in summer, during the summer drought. The maximum concentrations at that time were 5.4 ppbv on 8 August and 4.8 ppbv on 14 August and they coincided with two fast swelling events of the stem (Fig. 5) that resulted from precipitation events at the end of the drought period. However at the same time the decreased photosynthesis (GPP) and the probable stomatal closure during drought could also refer to potential soil emissions (Schade and Goldstein, 2001). Our results agree with the results of Asensio et al. (2007) who have presented that soil drought tend to increase the emissons rates of several VOCs.

In the autumn the level of methanol concentrations decreased. Some high and elevated concentrations were observed in September (2.4 ppbv on 13 September and $2.5 \mathrm{ppbv}$ on 23 September), which might be attributed to senescing and decaying biomass (Fall, 2003; Warneke et al., 1999). Due to a data gap in October we could not conclude the effect 

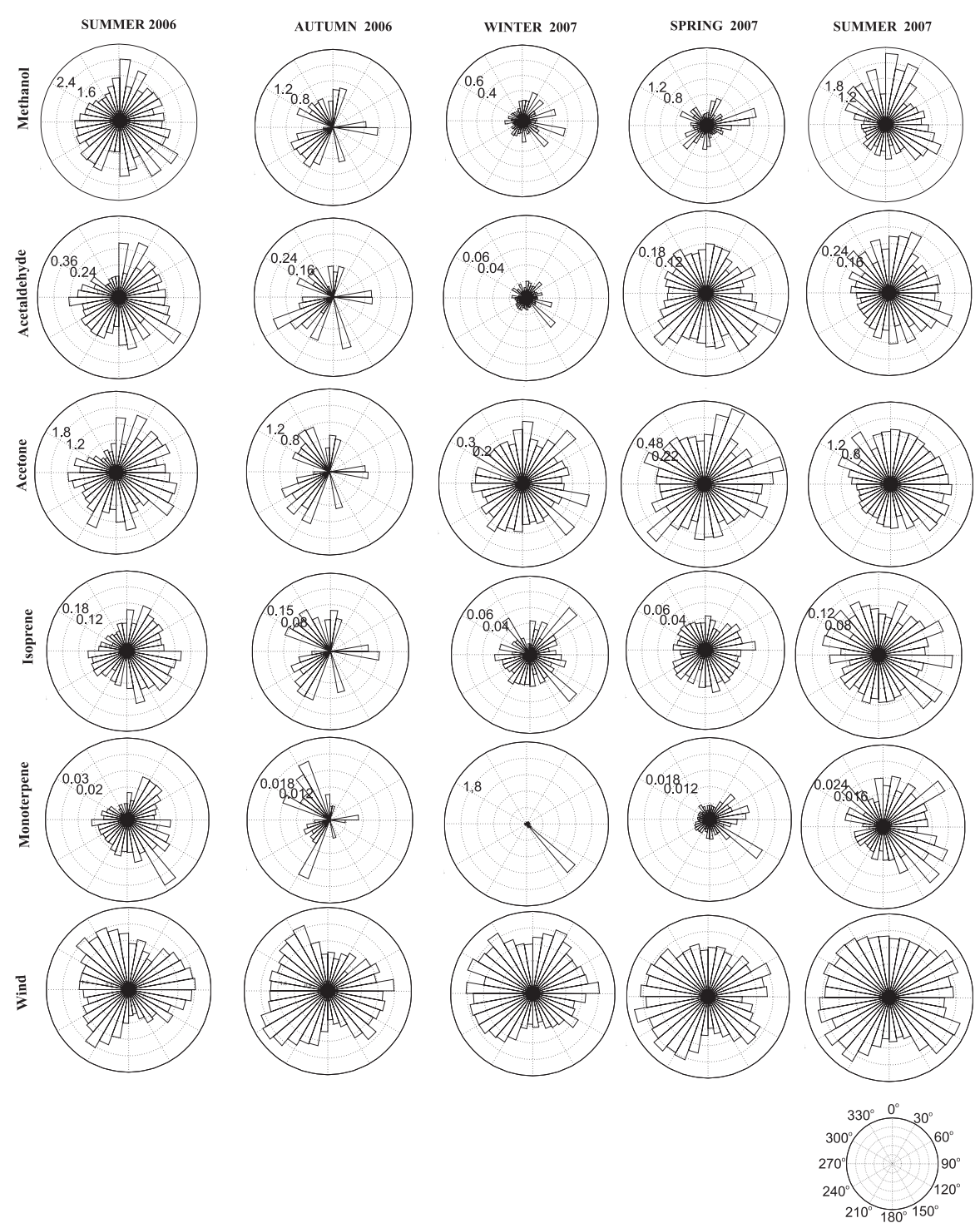

Fig. 2. Seasonal wind roses of wind ( $24 \mathrm{~h}$ - hourly data, $8.4 \mathrm{~m})$ at the SMEAR-II station in summer (June-July-August-2006), autumn (September-October-November 2006), winter (January-February 2007), in spring (March-April-May 2007) and summer 2007 (June-JulyAugust-2007).

of biological factors such as dormancy and defoliation on the measured concentrations or the emission capacity.

During winter the methanol concentrations stayed under $0.7 \mathrm{ppbv}$. They started to rise again in mid-March indicating close relationship with spring recovery of photosynthetic activity, which was observed in 2007 on 15 March (see Fig. 4). High concentration peaks of methanol, $1.6 \mathrm{ppbv}$, were also measured in the end of the snowmelt period, on 27 March. This might be due to release of methanol accumulated into or below the snow pack. Because of the high water solubility of methanol, the melting of snow might have produced emission bursts. Elevated concentrations during several days detected after mid-March coincided with the onset of photo- synthetic activity (GPP) (see Fig. 6). It is difficult to separate between the effects of the onset of photosynthesis and snow melt on the measured concentrations, because the two occurred almost simultaneously.

As earlier discussed, the increasing trend in methanol concentrations in late spring may reflect the increasing leaf biomass and the synthesis of the compound in the cell wall elongation processes (see Fall, 2003). Based on thermal time (Eq. 2) the onset of flowering for grey alder (Alnus incana) would have been on 14 April and the bud burst of birch (Betula pubescens) around 14 May. According to longterm recordings we estimate that budburst of aspen (Populus tremula) was around 27 May and the full leafing as attained 

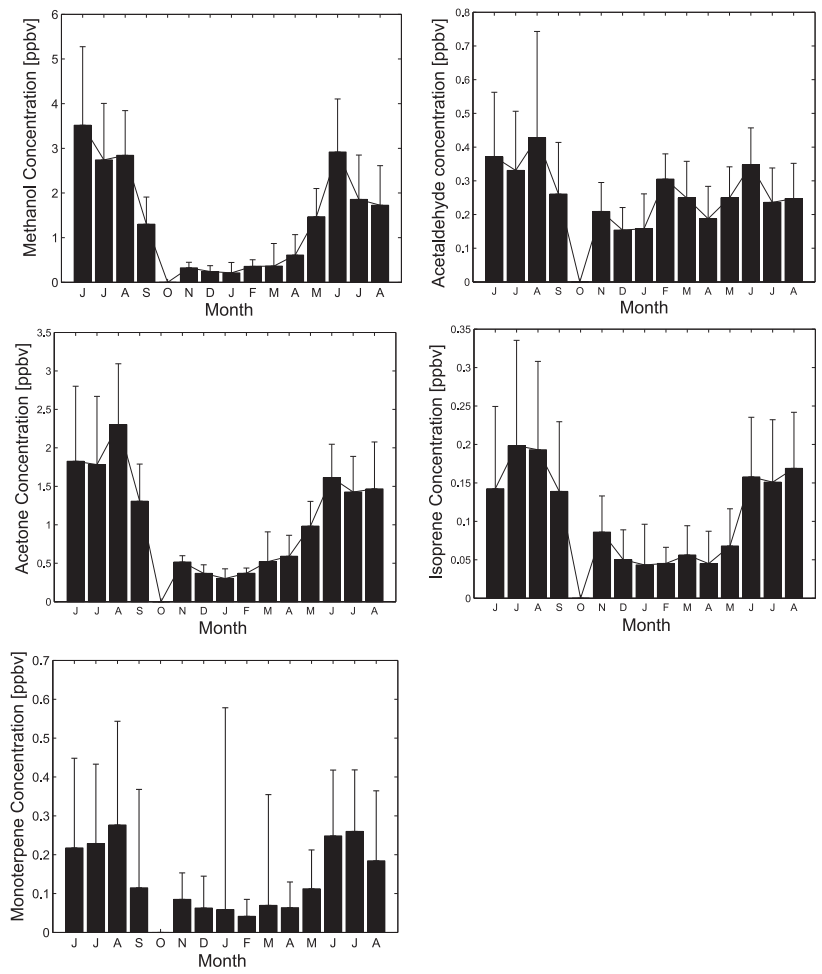

Fig. 3. Monthly day-time median values of BVOC concentrations at SMEAR II stations between June 2006 and August 2007.
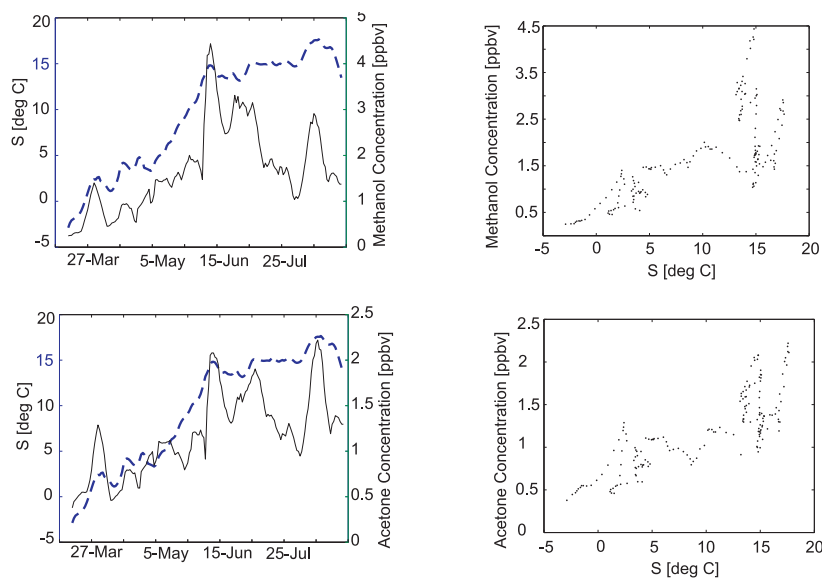

Fig. 4. An 8-day running median of BVOC concentrations versus state of development $(S)$ of methanol and acetone from March 15 to August 2007.

around May-June (Lappalainen and Heikinheimo, 1992) at the time when also the shoot growth of Scots pine started (Fig. 5).

In summer 2007 elevated concentrations were detected when the shoot and needle growth rates were at maximum. Earlier experiments have demonstrated high methanol fluxes in an aspen-oak forest just during the bud break and then a decline as leaves expanded. In both summers 2006 and 2007
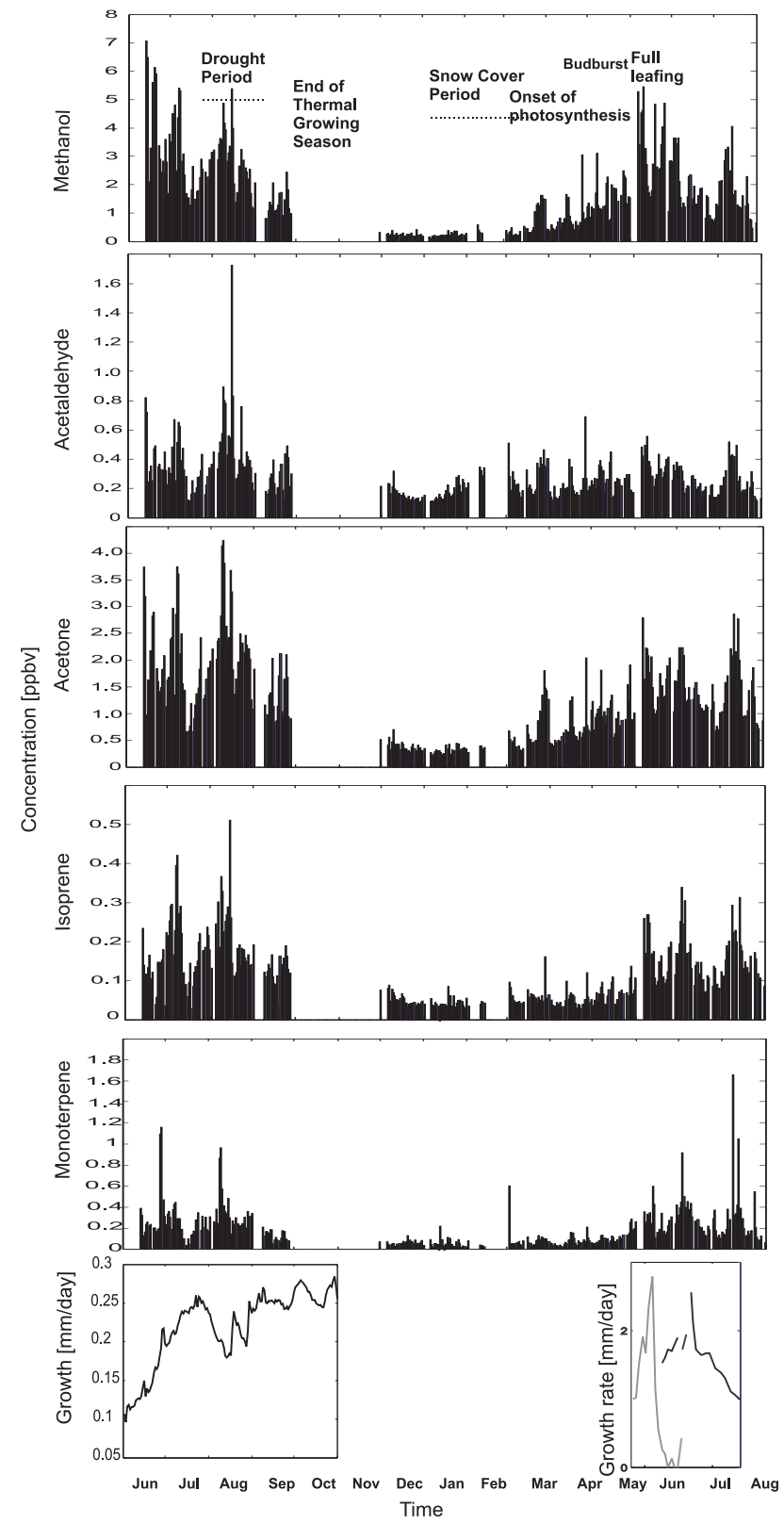

Fig. 5. A day-time median of BVOC concentrations (five top panels) during June 2006-May 2007 and the secondary growth of Scots pine stem $(1.3 \mathrm{~m})$ (1 June-30 October, 2006) and Scots pine shoot (blue) and needle (green) growth rate (21 May-8 August, 2007) (sixth panel). The exact days for the specific events marked in the figure are the following: Drought period (20 July-31 August), end of thermal growing season (24 October), snowcover period (15 January-27 March), onset of photosynthesis (15 March) and birch bud burst (Betula) (14 May).

we observed minimum in methanol concentrations when either the stem growth or shoot growth ceased.

Acetaldehyde. Contrary to other studied compounds we were not able to detect a clear seasonal variation in the acetaldehyde concentrations. Summer concentrations were in 

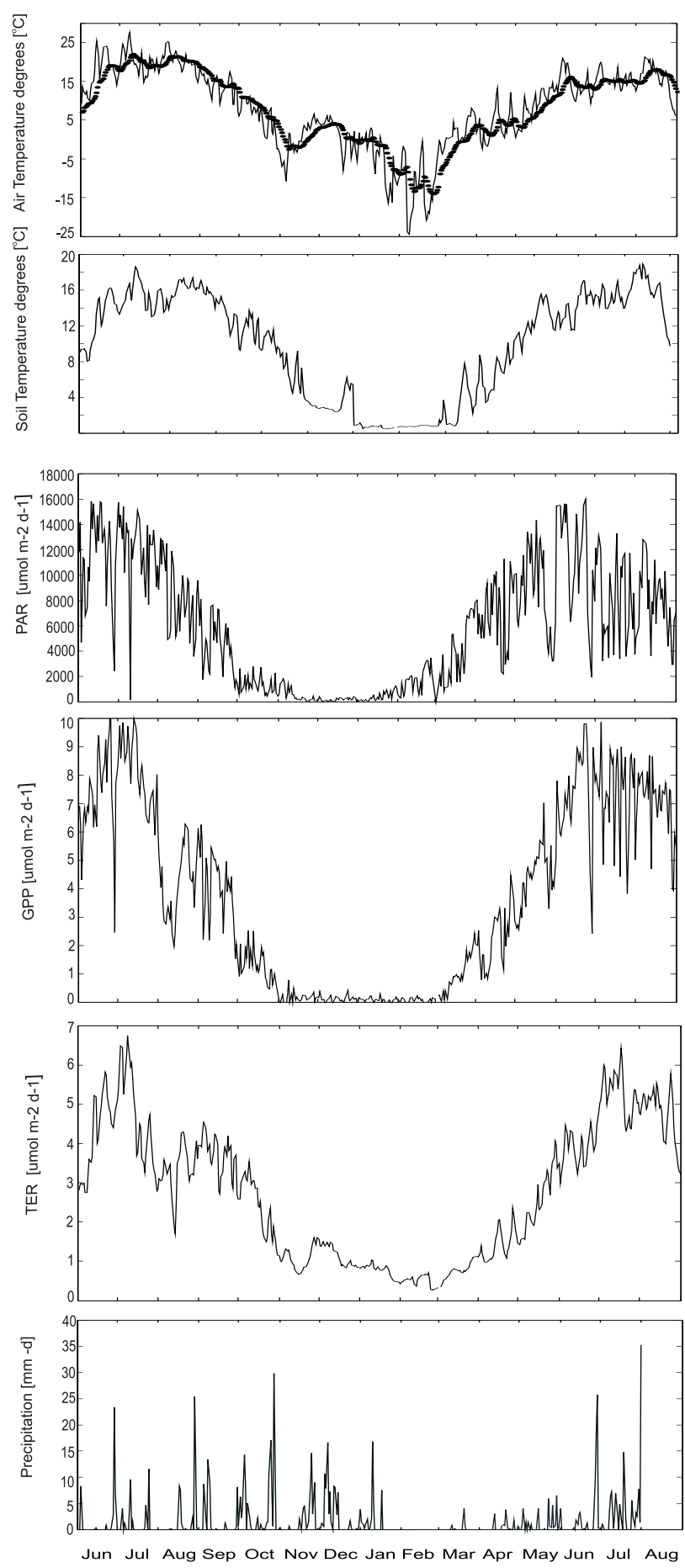

Fig. 6. Seasonal changes of meteorological factors and ecosystem gas exchange during the period 1 June, 2006-31 August, 2007 at SMEAR II station. In the top panel the thick line is the $S$ parameter (see Eq. 1) and the thin line is the air temperature. The values presented are the day-time daily medians.
2006 above and in 2007 below 0.3 ppbv (Fig. 3) and winter concentrations varied from 0.16 to $0.33 \mathrm{ppbv}$. Acetaldehyde is synthesized via several pathways especially under different stress conditions (Graus et al., 2004) which may cause more sporadic diurnal concentration peaks throughout the annual cycle. In our study the only clear longlasting stress event was the exceptional drought in summer 2006. The acetaldehyde maximum concentration, $1.7 \mathrm{ppbv}$, was observed during that period, on 13 August. After the drought, the monthly concentrations decreased towards winter and were at minimum (0.17 ppbv) in January (Fig. 5). In February and March, during the snow cover period, the concentrations were around $0.20 \mathrm{ppbv}$ fairly constantly. Because the low possible soil emissions due to snow cover and low biogenic sources due to the low GPP, the observed wintertime acetaldehyde concentrations might be attributed to antrophogenic sources. Near the timing of budburst some elevated acetaldehyde peaks could be detected, but compared to other compounds the increase was minor. In summer 2007 no specific peaks of acetaldehyde concentrations were observed.

Acetone. Scots pine and Norway spruce are the dominating tree species in SMEAR II and are known as significant source of acetone emissions (Janson and Serves, 2001). Acetone concentrations behaved similarly to methanol and had synchronous seasonal pattern and concentration peaks. The similar behavior of methanol and acetone is partly explained by their relatively long atmospheric lifetime, over 10 days (Atkinson and Arey, 2003).

In summers 2006 and 2007 acetone monthly daytime concentrations were around 1.5-1.7 ppbv (Fig. 3) with the highest measured peaks just under $4.5 \mathrm{ppbv}$ (Fig. 5). Similarly to methanol, these concentrations were lower than those reported for a mixed hardwood forest (5.6 ppbv) by Karl et al. (2003). This was the case even though Scots pine has been shown to emit methylbutenol (MBO) in mid-summer (Tarvainen et al., 2005), which could be an additional source for acetone also in our data. According to Goldstein and Schade (2000), direct biogenic acetone emissions accounted for about $35 \%$ of acetone concentrations in a ponderosa pine forest, whereas the oxidation of biogenic MBO contributed about twice as much to the acetone concentrations.

Similar to methanol and acetaldehyde, also the maximum summer concentration of acetone, $>4.0 \mathrm{ppbv}$, were measured during the drought period, on 8-10 August. In early September day-time concentration decreased to $0.8-2.2 \mathrm{ppbv}$ (Fig. 5). Karl et al.(2003) observed an emission peak in fall in a hardwood forest which could be attributed to the dying biomass like in the case of acetaldehyde. In winter the concentrations were clearly lower than $0.5 \mathrm{ppbv}$. In spring acetone concentrations increased again similar to methanol concentrations, and the photosynthetic capacity $(S)$ could predict the increase in acetone concentrations as well (Fig. 4).

Isoprene. Also isoprene concentrations showed a clear winter minimum and summer maximum. However, the 
springtime increase in isoprene concentrations was more abrupt than the increase in methanol and acetone (Fig. 3). The monthly median of the concentrations jumped from $0.07 \mathrm{ppbv}$ in May directly to $0.16 \mathrm{ppbv}$ in June. This increase was faster than the increase in photosynthetic capacity $(S)$, however $S$ could also explain springtime isoprene concentrations $(r=0.85)$ equally well as the increase in methanol and acetone concentrations (Fig. 4).

The summer concentrations of isoprene were above $0.14 \mathrm{ppbv}$ while the winter and early spring concentrations were below $0.06 \mathrm{ppbv}$ (Fig. 3). Interestingly, the winter time background concentrations and the concentrations in the spring were high compared to those measured by Hakola et al. (2000) in Eastern Finland, although the summer concentrations were similar (Hakola reported 3-8 pptv in May, 115155 pptv in June, 228-346 ppbv in July). The abrupt increase in isoprene concentrations in June was similar to the one reported by Hakola et al. (2000). The rapid rise in the early summer isoprene concentration could be explained by the capability of trees to synthesize and emit isoprenoids, which generally develops during the early stages after leaf emergence. In several tree species the onset of isoprenoid emissions has been observed to occur several days, up to weeks after full leaf expansion and gradually increase until the peak is reached in early summer (Fischbach et al., 2002; Hakola et al., 2001; Karl et al., 2003, Lindfors and Laurila, 2000). The full leaf area of deciduous trees was attained around the second week of June in Hyytiälä and may explain the elevated concentrations in June in both summers.

We detected six potential cases of elevated isoprene concentrations which could be attributed to biological activity (Fig. 5). There were three maxima in summer 2006: One in mid-June ( $0.25 \mathrm{ppbv})$, one in early July ( $>0.4 \mathrm{ppbv})$ and one in the end of August ( $>0.5 \mathrm{ppbv})$. All the peaks coincided with a rapid increase in the diameter of tree stems (Fig. 5). The first and the third occurred simultaneously with rainfall events, which resulted in stems swelling more than the growth rate alone would indicate. The second occurred at the time when the growth rate was highest. In August the increase in stem diameter after rain fall was most pronounced because the drought had lead to over-all shrinkage of the stems. Again in the end of spring 2007, the elevated isoprene concentrations occurred simultaneously with the maxima of the Scots pine shoot and needle growth rates. The peak in August 2007 occurred when soil temperature reached its maximum.

Monoterpenes. Like isoprene, the monthly median monoterpene concentrations increased rapidly in June (Fig. 3). The wintertime concentrations were below $0.1 \mathrm{ppbv}$. In May the concentration increased to 0.13 ppbv and in June the concentration was $>0.25 \mathrm{ppbv}$. Our concentrations were similar to those observed in a Scots pine forest in central Sweden (Janson, 1992) and the fast increase in June could also be seen in the measurements of Hakola et al. (2000).
The monoterpene peak concentrations relative to monoterpene base concentration were higher than the peaks of other compounds relative to their base concentration. The monoterpene peak concentrations were over five times higher than the base level, but for other compounds the largest difference was found for acetaldehyde where the 2006 summertime peak was about three times higher than the average concentration at that time (Fig. 5). Conifers possess significant monoterpene storage pools in their trunk and needles, which can be volatilized when temperatures are high enough, even though the de novo synthesis would be decreased due to lack of photosynthates. For monoterpenes the observed peak concentration could be enhanced by emissions from the storage pools. This could have been the case, especially, for the second peak in August 2006, when we observed high concentrations during the drought with decreased photosynthesis (GPP) (Fig. 6). Furthermore, all the peaks, except the first one in early July 2006 and the winter peak in early March occurred when air temperature increased above $20^{\circ} \mathrm{C}$. The first peak in 2006 appeared right after a rain fall event, when GPP and air temperature were in minimum. This concentration peak occurred earlier than the peaks for other compounds which took place when the air temperature increased after the rainfall. The peak concentration in mid-August 2007 occurred when soil temperature was at maximum. The high concentrations during the drought could also result from emissions from the soil (Asensio et al., 2007; Leff and Fierer, 2008).

The monoterpene concentrations started to decline soon after the summer drought had ceased. This might be associated with the leaf drop-out or senescence. Fischbach et al. (2002) have suggested that the capacity of monoterpene emission in Holm oak (Quercus ilex) declines with leaf age similarly to leaf photosynthetic potential. The decrease of concentrations could also be enhanced by high temperatures and the chemical reactions with $\mathrm{O}_{3}, \mathrm{OH}$ and $\mathrm{NO}_{3}$ in the air (Atkinson and Arey, 2003). The relatively high monoterpene concentrations in early March are puzzling: emissions should be rather low due to winter dormancy period and low temperatures. Tarvainen et al. (2005) and Hakola et al., (2006) have also reported high monoterpene emission rates in March and April at the same site. One possible explanation is a stress induced by a sudden cold spell, which may have caused an unbalance between the light and dark reactions of photosynthesis, and thus isoprenoid emissions as a consequence of energy overflow to the photosystem II (Penuelas and Munne-Bosch, 2005).

Relationships between compounds. The concentrations of the compounds were significantly correlated with each other (Table 2). The peak concentrations occurred simultaneously for all compounds except monoterpenes in June 2006. This happened even if the biological processes synthesizing BVOCs are different. The highest correlation was between methanol and acetone (0.88), which was similar to reported by Karl et al. (2003) and Rinne et al. (2005). Acetone 
Table 2. Correlation between different compounds (day-time medians) during the period between 1 June, 2006 to 31 May, 2007, winter months due to low biological activity omitted from the analysis $(n=333)$.

\begin{tabular}{lrrrr}
\hline- & M45 & M59 & M69 & M137 \\
\hline M33 & 0.72 & 0.88 & 0.74 & 0.52 \\
M45 & - & 0.81 & 0.69 & 0.47 \\
M59 & - & - & 0.83 & 0.62 \\
M69 & - & - & - & 0.66 \\
\hline
\end{tabular}

concentration was also well correlated with the concentrations of the other compounds. The correlations of monoterpene concentrations with other compounds were lowest (although $>0.45$ ). This is due to the monoterpene peak concentrations not always occurring simultaneously with peak concentrations of other compounds. Our results show that the concentrations can be driven by one or several environmental factors which, for example, strongly control their volatility (Penuelas and Llusia, 2004). It should also be kept in mind that the observed intercorrelation of compounds not only reflect emission processes, but may also relate to the fast atmospheric oxidation processes, where one compound is a product of another like acetone is for monoterpenes (Atkinson and Arey, 2003).

BVOCs emitted by plants can enter the atmosphere via two ways, either via stomatal pores and/or directly thought the cuticle. The emissions pathway into the air depends on the chemical character of the compound concerned. Methanol, acetone and acetaldehyde emissions are controlled by stomata more than isoprene and monoterpenes, which can also be released through the cuticle (Niinemets and Reichstein, 2003). It is interesting that the concentrations of all studied compounds peaked during the drought, when GPP was reduced because of stomatal closure. This indicates either some unaccounted sources or different processes regulating emissions under drought stress.

\subsection{Factors effecting BVOC concentrations in a boreal forest}

Of the environmental factors (air temperature (Tair), soil temperature (Tsoil), radiation (PPFD), photosynthesis (GPP) and total ecosystem respiration (TER) (Fig. 6), all the studied BVOC concentrations correlated best with day-time air temperature (Table 3). Also the correlations between BVOCs and biological factors (GPP and TER) were always weaker than the correlation with Tair. Soil temperature failed in explaining the concentrations especially in spring (frost) and during the summer drought (low soil water content). Weaker correlations between BVOC concentrations and GPP were particularly evident during the summer drought.
Table 3. Correlation between day-time BVOC concentrations and air temperature (Tair), soil temperature in the humus layer (Thum), photosynthetic active radiation (PPFD), photosynthesis (GPP), total ecosystem respiration (TER) during 1 June, 2006-31 August, 2007 (December-February-January omitted, $n=395$ ).

\begin{tabular}{lrrrrr}
\hline & Tair & Thum & PPFD & GPP & TER \\
\hline Methanol & 0.74 & 0.62 & 0.52 & 0.55 & 0.60 \\
Acetaldehyde & 0.42 & 0.32 & 0.13 & 0.11 & 0.20 \\
Acetone & 0.75 & 0.67 & 0.33 & 0.41 & 0.57 \\
Isoprene & 0.72 & 0.70 & 0.32 & 0.45 & 0.60 \\
Monoterpenes & 0.50 & 0.52 & 0.13 & 0.27 & 0.46 \\
\hline
\end{tabular}

The terpenoid emissions are often presented as a function of temperature alone (monoterpenes) or temperature together with light intensity (isoprene) (e.g. Monson et al., 1995; Guenther et al., 1995). We found that if the BVOC concentrations in our boreal pine forest stand are explained by one environmental factor, air temperature $(t)$ was the best. The concentrations were best described by an exponent function $y=a e^{(b t)}$ (Fig. 7). In general the temperature dependence functions of terpenoids and other compounds were quite similar. This was not a surprise because their concentrations were significantly correlated with each other. The temperature relationship could explain 65 or 67 percent of the variation in methanol, acetone and isoprene concentrations (see Fig. 7). For acetaldehyde and monoterpenes the degree of explanation was 24 and 29 percent, respectively. This low value may result from the different biosynthesis and emission pathways of these compounds. Acetaldehyde emissions are in many cases related to stress responses (Fall, 2003), which implies other regulatory factors besides temperature. In our case e.g. the periodic drought could have been stimulating the emission of acetaldehyde (Fig. 5).

Monoterpene concentrations had several distinct peaks, which did not follow the temperature response pattern of the rest of the monoterpene data. Monoterpene emissions from the coniferous foliage may originate from both de novo synthesis and permanent storage pools (Shao et al., 2001; Ghirardo et al., 2009). Therefore, the emissions are probably regulated by several factors. In a short term, temperature has an effect on the diffusion and the equilibrium coefficients between storage pools (Copolovici and Niinemets, 2005). However, the storage pool turnover rates depend also on the physical location and structure of the storage. If the storage is located in the liquid compartments (such as for example methanol or acetone), then the liberation of molecules from the storage may be more directly related to temperature than in the case when the storage is in lipid compartments or in specialized storage structures (such as most of the monoterpenes). 

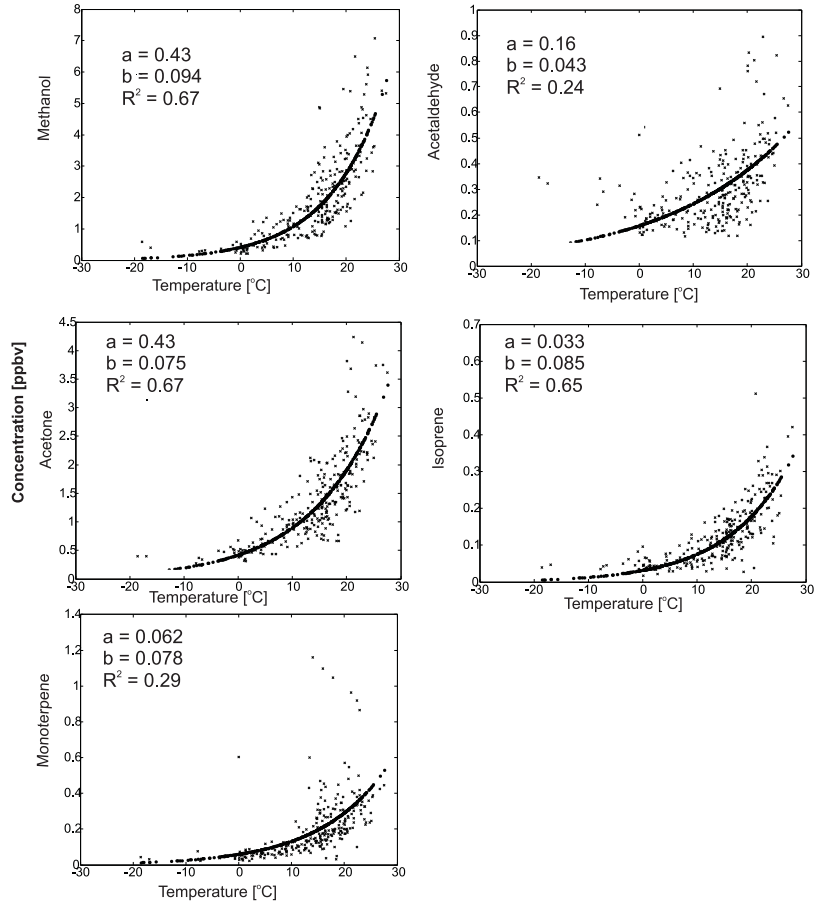

Fig. 7. The BVOC concentrations as a function of air temperature. The fitted curves were exponent functions, $y=a e^{(b t)}$, where $t=$ air temperature.

Air temperature is the driving factor behind biological activity in a long time scale (Hari and Kulmala, 2008). In addition to its direct effects through volatility, air temperature influences the BVOC emissions indirectly, by affecting leaf development and photosynthetic capacity and thereby also the biosynthesis of volatile compounds. Gray et al. (2006) used a variable describing thermal history to model the emissions of methyl butenol (MBO) from ponderosa pine foliage, in order to correct for seasonal changes in the standard emission capacity. This approach proved useful for MBO, but for other compounds it has not been properly tested. Our data suggest that also for methanol, acetone and monoterpenes some longer term temperature influence could be important. The specific role of temperature history and foliage development in the unforeseen high BVOC emissions during springtime warrants further studies, which are only possible with this kind of long time series of data.

\section{Conclusions}

The continuous day-time concentration measurements of isoprenoids and three oxygenated BVOCs in a boreal forest site, measured over fifteen months by highly sensitive PTRMS technique above a Scots pine canopy provide an excellent opportunity to connect the plant biological activity and BVOC emissions. The major part of the measured concen- trations originated from emissions from the local forest. Elevated concentrations were associated with seasonal events related to plant physiological turning points and changed environmental conditions. The studied compounds were highly correlated each other and were also closely correlated with air temperature. We could not distinguish different biogenic sources, but based on wind direction analyses most of the concentrations were representing the local forest. We also detected no decrease in BVOC concentrations during an exceptional summer drought although photosyntesis was low. We determined temperature dependence function for each compound in a boreal forest canopy scale. These functions were fit to data, which covered periods of summer drought, warm autumn and warm spring. However, it should be underlined that the responses can be different during other specific conditions for example in a cold summer.

Acknowledgements. We thank Eero Nikinmaa and Janne Korhonen for proving us daily shoot and needle growth data, Jukka Pumpanen for soil water data and Tiia Grönholm for wind rose MatLab code. This study is supported by EU-FP6 EUCAARI project No 036833-2 and the Kone Foundation.

Edited by: K. Carslaw

\section{References}

Asensio, D., Penuelas, J., Llusia, J. J., Ogaya, R., and Filella, I.: Interannual and interseasonal soil $\mathrm{CO}_{2}$ efflux and $\mathrm{VOC}$ exchange rates in a Mediterranean holm oak forest in response to experimental drought, Soil Biol. Biochemi., 3, 2471-2484, 2007.

Atkinson, R. and Arey, J.: Gas-phase tropospheric chemistry of biogenic volatile organic compounds: a review, Atmos. Environ., 37, 197-219, 2003.

Bäck, J., Hari, P., Hakola, H., Juurola, E., and Kulmala, M.: Dynamics of monoterpene emissions in Pinus sylvestris during early spring, Boreal Env. Res., 10, 409-424, 2005.

Copolovici, L. and Niinemets, U.:Temperature dependencies of Henry's law constants and octanol/water partition coefficients for key plant volatile monoterpenoids, Chemosphere, 61, 13901400, 2005.

Duursma, R. A., Kolari, P., Permki, M., Nikinmaa, E., Hari, P., Delzon, S., Loustau, D., Ilvesniemi, H., Pumpanen, J., and Mäkelä, A.: Predicting the decline in daily maximum transpiration rate of two pine stands during drought based on constant minimum leaf water potential and plant hydraulic conductance, Tree Physiol., 28, 265-276, 2008.

Fall, R.: Abundant Oxygenates in the Atmosphere: A Biochemical perspective, Chem. Rev., 103, 4941-4951, 2003.

Fischbach, R. J., Staudt, M., Zimmer, I., Rambal, S., and Schnitzler, J.-P.: Seasonal pattern of monoterpene synthase activities in leaves of the evergreen tree (Quercus ilex), Physiol. Plantarum, 114, 354-360, 2002.

Folkers, A., Hve, K., Ammann, C., Dindorf, T., Kesselmeier, J., Kleist, E., Kuhn, U., Uerlings, R., and Wildt, J.:Methanol emissions from deciduous tree species: dependence on temperature and light intensity, Plant Biol., 10, 65-75 2008. 
Galbally, I. E. and Kirstine, W.: The production of methanol by flowering plants and the global cycle of methanol, J. Atmos. Chem., 43, 195-229, 2002.

Ghirardo, A., Koch, K., Schnitzler, J.-P., and Rinne, J.: $13 \mathrm{CO}_{2}$ feeding experiment of four common European boreal tree species: 13C incorporation into monoterpenes. 4th International Conference on Proton Transfer Reaction Mass Spectrometry and its applications - Contributions, 16-21, 2009, Obergurgl, Austria, Conference Series, Innsbruck University Press, 219-220, 2009.

Goldstein, A. H. and Schade, G. W.: Quantifying biogenic and anthropogenic contributions to acetone mixing ratios in a rural environment, Atmos. Environ., 34, 4997-5006, 2000.

Graus, M., Schnitzler, J.-P., Hansel, A., Cojocariu, C., Rennenberg, H., Wisthaler, A., and Kreuzwieser, J.: Transient Release of Oxygenated Volatile Organic Compounds during Light-Dark Transitions in Grey Poplar leaves, Plant Physiol., 135, 1967-1975, 2004.

Gray, D. W., Goldstein, A. H., and Lerdau, M.:Thermal history regulates methylbutenol basal emission rate in Pinus ponderosa, Plant Cell Environ., 29, 1298-1308, 2006.

Grote, R. and Niinements, U.: Modeling volatile isoprenoid emissions - a story with split ends, Plant Biol. (Stuttg.), 10, 8-28, 2008.

Guenther, A.: Seasonal and spatial variations in natural volatile organic compound emissions, Ecol. Appl., 7, 34-45, 1997.

Guenther, A. B., Monson, R. K., and Fall, R.: Isoprene and monoterpene emission rate variability: Observations with Eucalytus and emission rate algorithm development, J. Geophys. Res., 96, 10799-10808, 1991.

Guenther, A., Hewitt, C. N., Erickson, D., Fall, R., Geron, C., Graedel, T., Harley, P., Klinger, L., Lerdau, M., Mckay, W. A., Pierce, T., Scholes, B., Steinbrecher, R., Tallamraju, R., Taylor, J., and Zimmerman, P.: A global model of natural volatile organic compounds emissions, J. Geophys. Res., 100, 8873-8892, 1995.

Hakola, H., Hellen, H., and Laurila, T.: Ten years of light hydrocarbons (C-2-C-6) concentration measurements in background air in Finland, Atmos. Environ., 40, 3621-3630, 2006.

Hakola, H., Laurila, T., Lindfors, V., Hellén, H., Gaman, A., and Rinne, J.: Variation of the VOC emission rates of birch species during the growing season, Boreal Env. Res., 6, 237-249, 2001.

Hakola, H., Laurila, T., Rinne, J., and Puhto, K.; The ambient concentrations of biogenic hydrocarbons at a northern European, boreal site, Atmos. Environ., 34, 4971-4982, 2000.

Hari, P. and Kulmala, M.: Station for measuring ecosystematmosphere relations (SMEAR II), Boreal Env. Res., 10, 315322, 2005.

Hari, P. and Kulmala L. (Eds.): Boreal forest and climate change, Advances in global change research, 34, Springer, 2008.

Ilvesniemi, H., Levula, J., Ojansuu, R., Kolari, P., Kulmala, L., Pumpanen, J., Launiainen, S., Vesala, T., and Nikinmaa, E.: Long-term measurements of the carbon balance of a boreal Scots pine dominated forest ecosystem, Boreal Env. Res., 14, 731-753, 2009.

Janson, R.: Monoterpene concentrations in and above a forest of scots pine, J. Atmos. Chem., 14, 385-394, 1992.

Janson, R., De Serves, C., and Romero, R.: Emission of isoprene and carbonyl compounds from a boreal forest and wetland in Sweden, Agr. Forest Meteorol., 98-99, 671-681, 1999.
Janson, R. and de Serves, C.: Acetone and monoterpene emissions from boreal forest i n northern Europe, Atmos. Environ., 35, 4629-4637, 2001.

Karl, T., Guenther, A., Spirig, C., Hansel, A., and Fall, R.: Seasonal variation of biogenic VOC emissions above a mixed hardwood forest in northern Michigan, Geophys. Res. Lett., 30, 2186, doi:10.1029/2003GL018432, 2003.

Karl, T., Harley, P., Guenther, A., Rasmussen, R., Baker, B., Jardine, K., and Nemitz, E.: The bi-directional exchange of oxygenated VOCs between a loblolly pine (Pinus taeda) plantation and the atmosphere, Atmos. Chem. Phys., 5, 3015-3031, 2005, http://www.atmos-chem-phys.net/5/3015/2005/.

Kolari, P., Lappalainen, H. K., Hänninen, H., and Hari, P.: Relationship between temperature and the seasonal course of photosynthesis in Scots pine at northern timberline and in southern boreal zone, Tellus B, 59, 542-552, 2007.

Kourtchev, I., Ruuskanen, T. M., Keronen, P., Sogcheva, L., Maso, D. M., Chi, X., Vermeyerl, R., Kulmala, M., Maenhaut, W., and Claeys, M.: Determination of isoprene and $\alpha-/ \beta$-pinene oxidation products in boreal forest aerosols from Hyytiälä, Finland: diurnal variations and possible links with particle formation events, Plant Biol., 10, 138-149, 2008.

Kreuzwieser, J., Harren, F. J. M., Laarhoven, L. J. J., Boamfa, I., te Lintel-Hekkert, S., Scheerer, U., Hüglin, C., and Rennenberg, H.: Acetaldehyde emission by the leaves of trees - correlation with physiological and environmental parameters, Physiol. Plantarum, 113, 41-49, 2001.

Kreuzwieser, J., Papadopoulou, E., and Rennenberg, H.: Interaction of flooding with carbon metabolism of forest trees, Plant Biol., 6, 299-306, 2004.

Kulmala, M., Riipinen, I., Sipil, M., Manninen, H. E., Petäjä, T., Junninen, H., Dal Maso, M., Mordas, G., Mirme, A., Vana, M., Hirsikko, A., Laakso, L., Harrison, R. M., Hanson, I., Leung, C., Lehtinen, K., and Kerminen, V.-M.: Toward Direct Measurement of Atmospheric Nucleation, Science, 318, 89-92, 2007.

Kulmala, M., Suni, T., Lehtinen, K. E. J., Dal Maso, M., Boy, M., Reissell, A., Rannik, Ü., Aalto, P., Keronen, P., Hakola, H., Bäck, J., Hoffmann, T., Vesala, T., and Hari, P.: A new feedback mechanism linking forests, aerosols, and climate, Atmos. Chem. Phys., 4, 557-562, 2004, http://www.atmos-chem-phys.net/4/557/2004/.

Lappalainen, H. and Heikinheimo, M.: Relations between climate and plant phenology. Part 1. survey of plant phenological observations in Finland from 1896 to 1965, Meteorological publications, No. 20, 34 pp., 1992.

Leff, J. W. and Fierer, N.: Volatile organic compound (VOC) emissions from soil and litter samples, Soil Biol. Biochem., 40, 16291636, 2008.

Legreida, G., Löövb, J. B., Staehelinb, J., Hueglina, C., Hilla, M., Buchmanna, B., Prevotc, A. S. H., and Reimanna, S.: Oxygenated volatile organic compounds (OVOCs) at an urban background site in Zürich (Europe): Seasonal variation and source allocation, Atmos. Environ., 41, 8409-8423, 2007.

Lindinger, W., Hansel, A., and Jordan, A.: On-line monitoring of volatile organic compopunds at pptv levels by means of ProtonTransfer-Reaction Mass Spectrometry (PTR-MS) - Medical applications, food control and environmental research, Int. J. Mass Spectrom., 173, 191-241, 1998.

Linkosalo, T., Lappalainen, H. K, and Hari, P.: Comparision of phe- 
nological models of leaf bud burts and flowering of borela trees using independent observation data, Tree Physiol., 28, 18731882, 2008.

Linkosalo,T. and Lechowicz, M.: Twilight far-red treatment advances leaf bud burst of silver birch (Betula pendula), Tree Physiol., 26, 1249-1256, 2006.

Lindfors, V. and Laurila, T.: Biogenic volatile organic compound (VOC) emissions from forests in Finland, Boreal Env. Res., 5, 95-113, 2000.

Monson, R., Lerdau, M., Sharkey, T., and Schimel, D.: Biological aspects of construction organic compound emission inventories, Atmos. Environ., 29, 2989-3002, 1995.

Mäkelä, A., Hari, P., Berninger, F., Hänninen, H., and Nikinmaa, E.: Acclimation of photosynthetic capacity in Scots pine to the annual cycle temperature, Tree Physiol., 24, 369-378, 2004.

Mäkelä, A., Kolari, P., Karimäki, J., Nikinmaa, E., Perämäki, M., and Hari, P.: Modelling five years of weather-driven variation of GPP in a boreal forest, Agr. Forest Meterol., 139, 382-398, 2006.

Niinemets, U. and Reichstein, M.: Controls on the emission of plant volatiles through stomata: Differential sensitivity of emission rates to stomatal closure explained, J. Geophys. Res., 108(D7), 4208, doi:10.1029/2002JD002620, 2003.

Niinemets, U., Tenhunen, J. D., Harley, P. C., and Steinbrecher, R.: A model of isoprene emission based on energetic requirements for isoprene synthesis and leaf photosynthetic properties for Liquidambar and Quercus, Plant Cell Environ., 22, 13191335, 1999.

Öquist, G. and Huner, N.: Photosynthesis of overwintering evergreen plants, Annual Review of Plant Biology, 54, 329-355, 2003.

Owen, S. M. and Penuelas, J.: Opportunistic emissions of volatile isoprenoids, TRENDS in Plant Science, 10, 420-426, 2005.

Penuelas, J. and Llusia, J.: Plant VOC emissions: making use of the unavoidable, TRENDS in Ecology and Evolution, 19, 402-404, 2004.

Penuelas, J. and Munne-Bosch, S.: Isoprenoids: an evolutionary pool for photoprotection, TRENDS in Plant Science, 10, 166$169,2005$.

Rinne, J., Ruuskanen, T. M., Reissell, A., Taipale, R., Hakola, H., and Kulmala, M.: On-line PTR-MS measurements of atmospheric concentrations of volatile organic compounds in a European boreal forest ecosystem, Boreal Env. Res., 10, 425-436, 2005.

Rinne, J., Taipale, R., Markkanen, T., Ruuskanen, T. M., Hellén, H., Kajos, M. K., Vesala, T., and Kulmala, M.: Hydrocarbon fluxes above a Scots pine forest canopy: measurements and modeling, Atmos. Chem. Phys., 7, 3361-3372, 2007, http://www.atmos-chem-phys.net/7/3361/2007/.

Ruuskanen, T. M., Taipale, R., Rinne, J., Kajos, M. K., Hakola, H., and Kulmala, M.: Quantitative long-term measurements of VOC concentrations by PTR-MS: annual cycle at a boreal forest site, Atmos. Chem. Phys. Discuss., 9, 81-134, 2009,

http://www.atmos-chem-phys-discuss.net/9/81/2009/.
Sarvas, R.: Investigations on the annual cycle of development of forest trees. Active period, Communicationes Instituti Forestalis Fenniae, 76, 1-110, 1972.

Schade, G. W. and Goldstein, A. H.: Fluxes of oxygenated volatile organic compounds from a ponderosa pine plantation, J. Geophys. Res.-Atmos., 106, 3111-3123, 2001.

Schade, G. W. and Goldstein, A. H.: Seasonal measurements of acetone and methanol: Abundances and implications for atmospheric budgets, Global Biogeochem. Cy., 20, GB1011, doi:10.1029/2005GB002566, 2006.

Sevanto, S., Hölttä, T., Markkanen, T., Perämäki, M., Nikinmaa, E., and Vesala, T.: Relationships between diurnal xylem diameter variation and environmental factors in Scots pine, Boreal Env. Res., 10, 447-458, 2005.

Shao, M., Czapiewski, K. V., Heiden, A. C., Kobel, K., Komenda, M., Koppman, R., and Wildt, J.: Volatile organic compound emissions from Scots pine: Mechanisms and description by algorithms, J. Geophys. Res., 106, 20483-20491, 2001.

Taipale, R., Ruuskanen, T. M., Rinne, J., Kajos, M. K., Hakola, H., Pohja, T., and Kulmala, M.: Technical Note: Quantitative long-term measurements of VOC concentrations by PTR-MS measurement, calibration, and volume mixing ratio calculation methods, Atmos. Chem. Phys., 8, 6681-6698, 2008, http://www.atmos-chem-phys.net/8/6681/2008/.

Tarvainen, V., Hakola, H., Hellén, H., Bäck, J., Hari, P., and Kulmala, M.: Temperature and light dependence of the VOC emissions of Scots pine, Atmos. Chem. Phys., 5, 989-998, 2005, http://www.atmos-chem-phys.net/5/989/2005/.

Tingey, D., Manning, M., Grothaus, L., and Burns W. F.: Influence of light and temperature on monoterpene emission rates from Slash pine, Plant. Physiol. 65, 797-801, 1980.

Tunved, P., Korhonen, H., Strom, J., Hansson, H. C., Lehtinen, K. E. J., and Kulmala, M.: Is nucleation capable of explaining observed aerosol integral number increase during southerly transport over Scandinavia?, Tellus B, 58, 129-140, 2006.

Vesala, T., Haataja, J., Aalto, P., et al.: Long-term field measurements of atmosphere-surface interactions in boreal forest ecology, micrometeorology, aerosol physics and atmospheric chemistry, Trends in Heat, Mass and Momentum Transfer, 4, 17-35, 1998.

Warneke, C., Karl, T., Judmaier, H., Hansel, A., Jordan, A., Lindinger, W., and Crutzen, P. J.: Acetone, methanol and other partially oxidized volatile organic emissions from dead plant matter by abiological processes: significance for atmospheric $\mathrm{HO}_{\mathrm{x}}$ chemistry, Global Biogeochem. Cy., 13, 9-15, 1999. 